\title{
Optimization for Production and Partial Purification of Laccase from Ash Gourd Peels
}

\author{
Surabhi Mitra ${ }^{1,2}$, Kanhaiya Tiwari ${ }^{1}$ and Shailendra Kumar Srivastava ${ }^{1} *$ \\ ${ }^{1}$ Department of Biochemistry and Biochemical Engineering, Jacob School of Biotechnology and \\ Bioengineering, Sam Higginbottom Institute of Agriculture Technology and Sciences, \\ Allahabad-211007, India \\ ${ }^{2}$ Department of Biotechnology, MNNIT, Allahabad- 211004, India \\ *Corresponding author
}

\section{A B S T R A C T}

\begin{tabular}{|c|c|}
\hline Keywords & The aim of the present study was to optimize a process for production enzyme \\
\hline $\begin{array}{l}\text { Laccase, } \\
\text { Ash Gourd, } \\
\text { Trichoderma } \\
\text { viride }\end{array}$ & $\begin{array}{l}\text { Laccase via microbial fermentation using peels of Ash Gourd. It is rich in various } \\
\text { nutritional substances which are required for culture of microorganisms.. By } \\
\text { estimating proximate values of various substances a synthetic media was prepared } \\
\text { for Trichoderma Viride. Laccases were collected extra and intracellular level. The }\end{array}$ \\
\hline Article Info & enzyme activity, growth was observed which were treated in various conditions \\
\hline $\begin{array}{l}\text { Accepted: } \\
\text { 20 January } 2017 \\
\text { Available Online: } \\
\text { 10 February } 2017\end{array}$ & 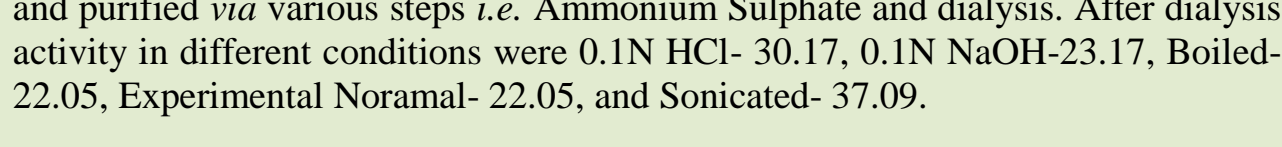 \\
\hline
\end{tabular}

\section{Introduction}

Organic waste is produced wherever there is human habitation. The main forms of organic waste are household food waste, agricultural waste, human and animal waste. In industrialized countries the amount of organic waste produced is increasing dramatically each year. Likewise, these organic wastes can be used to produce many industrially useful enzymes. In Allahabad (Uttar Pradesh) there are several Petha producing industries are established at various locations of Allahabad i.e. Muttiganj, Kidganj, etc. These Petha industries utilize Ash Gourd as primary raw material for the production of Petha but the peel of winter melon discarded as waste.
Everyday approx 600-800 kg of Ash Gourd peel is thrown as waste, which covers a large area leading to land pollution.

The peels of ash guard are rich in sugar, protein, carbohydrates, methionine, amylose, phytate, oxalate, proline and phenolic components in large amount. Since ash gourd peels having these content can be provided as a substrate for growth of the various microorganism which can be used to produce industrially important products like enzyme i.e., Laccase, Cellulase and so, organic acid, vitamins etc., by microbial fermentation. So by this study we try to standardize Ash Gourd 
peel, a new substrate to produce Laccase from Trichoderma viride.

\section{Materials and Methods}

Collection of ash guard peels: A well established small scale industry of Petha sweet is situated in Rambagh, BI KA BAGH, etc. local markets of Allahabad.

Total moisture content: The total moisture content was estimated by the method of A.O.A.C, (1965).

Ash content (organic portion): The total ash content was estimated by the method of A.O.A.C., (1965).

Estimation of starch: Starch was estimated by the process explained in Standard Methods of Biochemical Analysis edited by Thayumanavan and Sadasivam (1984) the intensity of green to dark green colour was read at 630nm taking Glucose as Standard (working standard $100 \mu \mathrm{g} / \mathrm{ml}$ ).

Determination of total soluble sugar: The determination of total sugar was elucidated by the method of Hedge et al., (1962) and measured the green to dark green colour at $630 \mathrm{~nm}$ using glucose as standard.

Determination of reducing sugar: The determination of reducing sugar was estimated by the method of Nelson (1952), taking glucose as standard (working standard $100 \mu \mathrm{g} / \mathrm{ml})$ at $630 \mathrm{~nm}$.

Protein estimation: The total protein content was estimated by the method of Lowry et al., (1951), Taking the reading of sample at $660 \mathrm{~nm}$ against standard Bovine Serum albumin (BSA) curve.

Methionine: Methionine was estimated by the method of Horn et al., (1946), intensity of red color was measured at 520nm against a blank prepared without nitroprusside.

Proline: Proline was estimated by the method of Bates et al., (1973) and measured the red colour at 520nm against a reagent blank.

Oxalate: Oxalate was determined by the method of Day and Underwood (1986). The oxalate content was then calculated by taking $1 \mathrm{ml}$ of $0.05 \mathrm{~m} \mathrm{KMnO}_{4}$ as equivalent to $2.2 \mathrm{mg}$ oxalate.

Amylose: Amylose was determined using method of Sadasivam and S. Manickam (1992).

Reading was measured at $590 \mathrm{~nm}$ against standard amylose sugar.

Maltose: It was estimated by using method of Jayaraman (1981). Orange red color was read at $520 \mathrm{~nm}$ against a reagent blank.

Cellulose: Cellulose was estimated by the method of Updegroff and D.M. (1969) measured the sample at $630 \mathrm{~nm}$ against Anthrone reagent as bank.

Phytate content: Phytate was determined using Reddy and Love (1999) the content was titrated with Iron (III) chloride solution until a brownish-yellow color that persisted for 5 min was obtained.

Phenols: The total phenol content was estimated by method of Bray and Thorpe (1954). Different concentration of catechol measured at $650 \mathrm{~nm}$ for standard.

Ascorbic acid (Vitamin C): Estimated by the process of Hariss et al., (1935) the sample was titrated against the dye.

Estimation of crude fiber: Crude fiber was estimated by the process of Mynard et al., (1970) 
Estimation of crude fat: Estimation of fat was done by the method of AOAC (1965).

Fungal strain and growth conditions (Standard media): The fungus, Trichoderma Viride sp., which was used in this study, was collected from Department of Microbiology and Fermentation Technology (J. S. B. B., SHIATS). Fungus was cultivated overnight in PDA media this media consisted $(\mathrm{g} / \mathrm{l})$ of: Peptone-0.5, Urea-0.15, $\left(\mathrm{NH}_{4}\right)_{2} \mathrm{SO}_{4}-0.7$, $\mathrm{KH}_{2} \mathrm{PO}_{4}-1.0, \quad \mathrm{CaCl}_{2}-0.3, \quad \mathrm{MgSO}_{4} \cdot \mathrm{H}_{2} \mathrm{O}-0.15$, $\mathrm{FeSO}_{4} \cdot \mathrm{H}_{2} \mathrm{O}-2.5, \mathrm{MnSO}_{4} \cdot \mathrm{H}_{2} \mathrm{O}-0.8, \mathrm{ZnSO}_{4} \cdot \mathrm{H}_{2} \mathrm{O}$ -0.007 and $\mathrm{COCl}_{2}-0.001$ and maintained the media at $\mathrm{pH} 6.5$ for maximum cultivation followed by autoclaving the synthetic media at $121^{\circ} \mathrm{C}(15 \mathrm{psi})$ for $15 \mathrm{~min}$. After cooling the media flask $T$. Viride was inoculated in Laminar Air Flow for $96 \mathrm{~h}$.

Substrate media for fugal growth: The substrate media was prepared for the growth of $T$. Viride according to the percentage content of Ash Gourd peel which was determined in the laboratory protein-12.7\%, crude fibre- $11 \%$, crude fat $-0.5 \%$, total soluble sugar-30\%, reducing sugar- $0.002 \%$, maltose $0.009 \%$, total phenol- $1.84 \mathrm{mg} / \mathrm{ml}$, carbohydrate/ starch- $0.27 \mu \mathrm{g} / \mathrm{ml}$, amylose$0.36 \%$.

Submerged fermentation: The peel substrate was grinded and in 5 different flasks about $5 \mathrm{gm}$ of powder of peel was taken with $75 \mathrm{ml}$ of $0.1 \mathrm{~N} \mathrm{HCl}$ (Flask 1), $0.1 \mathrm{~N} \mathrm{NaOH}$ (Flask 2), Distilled water (Flasks 3,4 and 5)was added to $5(100 \mathrm{ml})$ Erlenmeyer flasks to provide different conditions i.e. Hydrolysis (Boiled and Unboiled), Acid Hydrolysis ( $\mathrm{HCl}-0.1 \mathrm{~N})$, Alkaline Hydrolysis $(\mathrm{NaOH}-0.1 \mathrm{~N})$, Sonicated for $1 \mathrm{~h}, \mathrm{pH}-5.5-6.5$ was maintained and then autoclaved. After autoclaving, one full loop culture of $T$. Viride was inoculated in the Erlenmeyer flasks. Flasks were incubated on rotatory shaker at $30 \circ \mathrm{C}$ for $120 \mathrm{~h}$.
Preparation of crude enzyme extract: Fungus growth was carried out in the 5 flasks which were treated in different conditions as mentioned earlier. For optimization, quantitative analysis of Protein, Reducing Sugars, Specific activity was processed by pipetting out $5 \mathrm{ml}$ of fungal broth media in cooling centrifuge tubes, and was centrifuged at $10,000 \mathrm{rpm}, 4^{\circ} \mathrm{C}$ for 20 minutes to obtain supernatant and pellet. The supernatant was then used as crude intracellular enzyme extract.

Purification of enzyme: The Laccase were purified from the crude enzyme in the following process - Ammonium sulphate precipitation and applied for dialysis.

\section{Results and Discussion}

Proximate analysis of ash gourd peel: The study on the proximate composition/component of the Ash Gourd peel has been carried out using recommended method of analysis.

The result of the analysis shows that were moisture content- $92.4 \%$, ash-1.6\%, protein$12.7 \%$, crude fibre- $11 \%$, crude fat $-5.5 \%$, total soluble sugar- $30 \%$, reducing sugar- $0.002 \%$, total phenol- $1.84 \mathrm{mg} / \mathrm{ml}$, carbohydrate 0.27 $\mu \mathrm{g} / \mathrm{ml}$, amylase- $0.36 \%$, maltose- $0.009 \%$, cellulose $-0.45 \mathrm{mg} / \mathrm{ml}$, proline- $0.5 \mu \mathrm{g} / \mathrm{ml}$, methionine- $6.0 \mathrm{mg} / \mathrm{g}, \quad$ ascorbic acid$138.6 \mathrm{mg} / \mathrm{ml}$, oxalate- $2.49 \mathrm{mg} / \mathrm{g}$., respectively. Earlier these findings were reported by Zoya et al., (2014).

Submerged fermentation process: Enzyme production by micro organisms is greatly influenced by media components, especially carbon, nitrogen sources and physical factors such as temperature, $\mathrm{pH}$, and incubation time and inoculums density. It is important to produce the enzyme in inexpensive and 
optimized media on a large scale for the process to be commercially viable, hence the studies on the influence of various physicochemical parameters such as incubation periods on production of enzyme.

Table.1 Protein content at various incubation time intervals

\begin{tabular}{|l|l|l|l|l|l|}
\hline $\begin{array}{l}\text { Incubation } \\
\text { Time (h) }\end{array}$ & $\begin{array}{l}\text { 0.1N HCl } \\
\text { Treated }\end{array}$ & $\begin{array}{l}\text { 0.1N NaOH } \\
\text { Treated }\end{array}$ & Boiled & $\begin{array}{l}\text { Experimental } \\
\text { Normal }\end{array}$ & Sonicated \\
\hline 24 & 0.192 & 0.141 & 0.411 & 0.211 & 0.566 \\
\hline 48 & 0.432 & 0.322 & 0.425 & 0.266 & 0.701 \\
\hline 72 & 0.802 & 0.855 & 0.622 & 0.421 & 0.824 \\
\hline 96 & 0.899 & 0.922 & 0.899 & 0.433 & 0.902 \\
\hline 120 & 1.022 & 1.100 & 0.933 & 0.845 & 1.102 \\
\hline
\end{tabular}

Table.2 Laccase activity $\left(\mathrm{IU} \mathrm{ml}{ }^{-1}\right)$ at various incubation time intervals

\begin{tabular}{|l|l|l|l|l|l|}
\hline $\begin{array}{l}\text { Incubation } \\
\text { Time (h) }\end{array}$ & $\begin{array}{l}\mathbf{0 . 1 N} \mathbf{H C l} \\
\text { Treated }\end{array}$ & $\begin{array}{l}\mathbf{0 . 1 N} \mathbf{N a O H} \\
\text { Treated }\end{array}$ & Boiled & $\begin{array}{l}\text { Experimental } \\
\text { Normal }\end{array}$ & Sonicated \\
\hline 24 & 0.151 & 0.78 & 1.30 & 0.64 & 4.77 \\
\hline 48 & 0.88 & 0.94 & 1.32 & 1.35 & 1.09 \\
\hline 72 & 0.33 & 0.60 & 0.495 & 0.42 & 0.54 \\
\hline 96 & 0.63 & 4.2 & 1.17 & 3.51 & 1.45 \\
\hline 120 & 0.82 & 2.17 & 2.52 & 1.905 & 1.11 \\
\hline
\end{tabular}

Table.3 Reducing sugars content at various incubation time intervals

\begin{tabular}{|l|l|l|l|l|l|}
\hline $\begin{array}{l}\text { Incubation } \\
\text { Time (h) }\end{array}$ & $\begin{array}{l}\text { 0.1N HCl } \\
\text { Treated }\end{array}$ & $\begin{array}{l}\text { 0.1N NaOH } \\
\text { Treated }\end{array}$ & Boiled & $\begin{array}{l}\text { Experimental } \\
\text { Normal }\end{array}$ & Sonicated \\
\hline 24 & 3.36 & 4.56 & 9.585 & 9.225 & 8.76 \\
\hline 48 & 1.62 & 2.535 & 7.275 & 5.265 & 5.145 \\
\hline 72 & 1.47 & 2.11 & 5.43 & 4.905 & 4.425 \\
\hline 96 & 1.23 & 1.42 & 4.02 & 2.715 & 3.22 \\
\hline 120 & 0.63 & 1.245 & 2.67 & 2.43 & 3.15 \\
\hline
\end{tabular}

Table.4 Laccase activity $\left(\mathrm{IU} \mathrm{ml}^{-1}\right)$ at various steps of purification process

\begin{tabular}{|c|l|c|c|c|c|c|}
\hline S.No. & Treatment & $\mathbf{0 . 1 N}$ HCl & $\begin{array}{l}\mathbf{0 . 1} \mathbf{N} \\
\text { NaOH }\end{array}$ & Boiled & $\begin{array}{l}\text { Exp. } \\
\text { Normal }\end{array}$ & Sonicated \\
\hline $\mathbf{1}$ & Crude & 10.05 & 7.07 & 9.56 & 8.05 & 8.14 \\
\hline $\mathbf{2}$ & $\begin{array}{l}\text { Ammonium Sulphate } \\
\text { precipitation. }\end{array}$ & 20.05 & 15.075 & 22.56 & 14.5 & 20.145 \\
\hline $\mathbf{3}$ & Dialysis & 30.17 & 23.17 & 38.18 & 22.05 & 37.098 \\
\hline
\end{tabular}


Fig.1 Graphical representation of protein content at various incubation time intervals

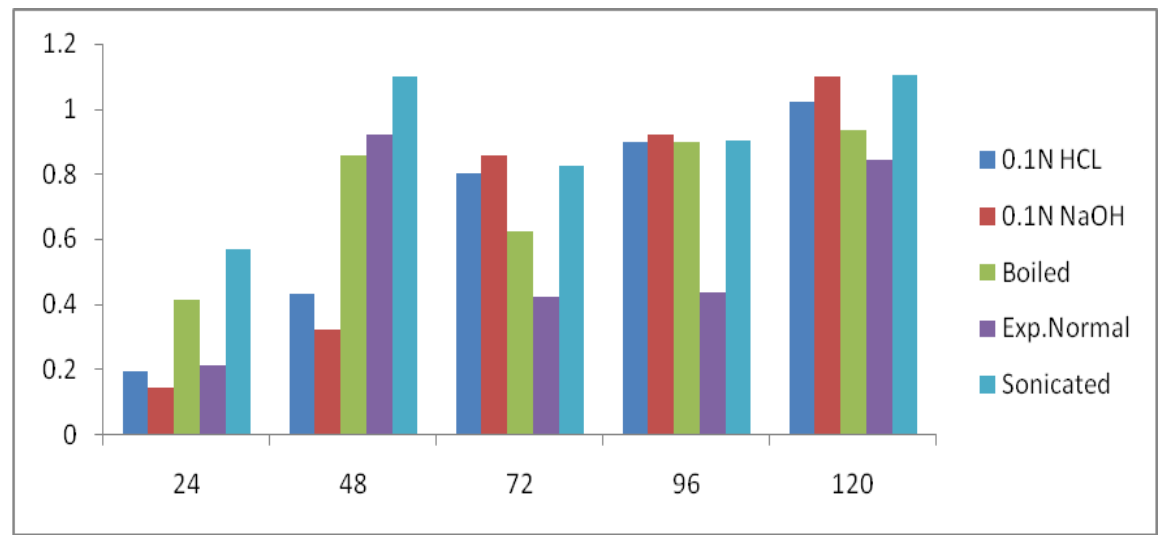

Fig.2 Graphical representation of laccase activity (IU ml-1) at various incubation time intervals

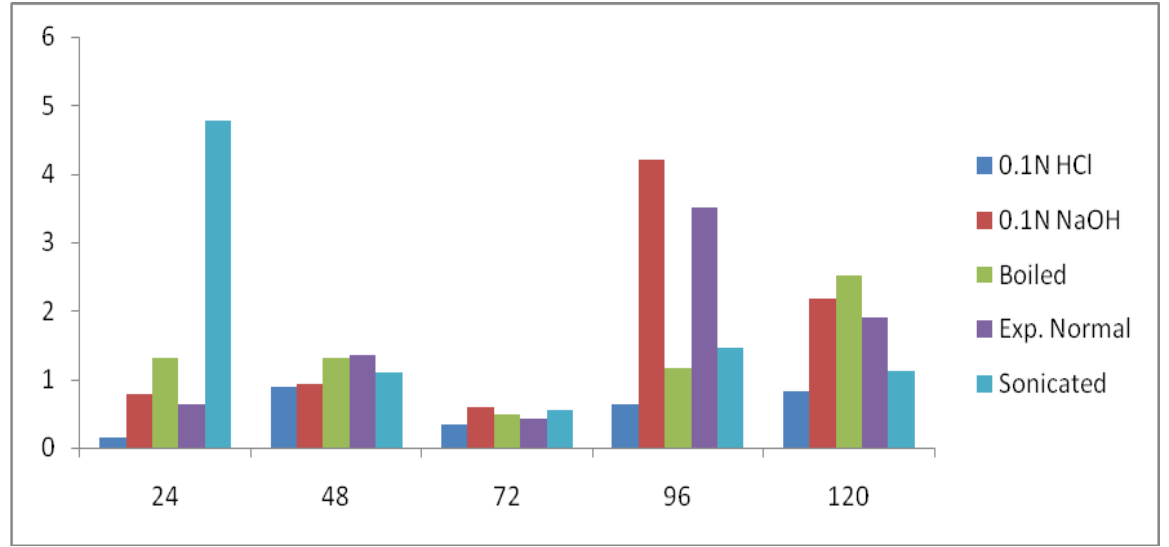

Fig.3 Graphical representation of reducing sugars content at various incubation time intervals

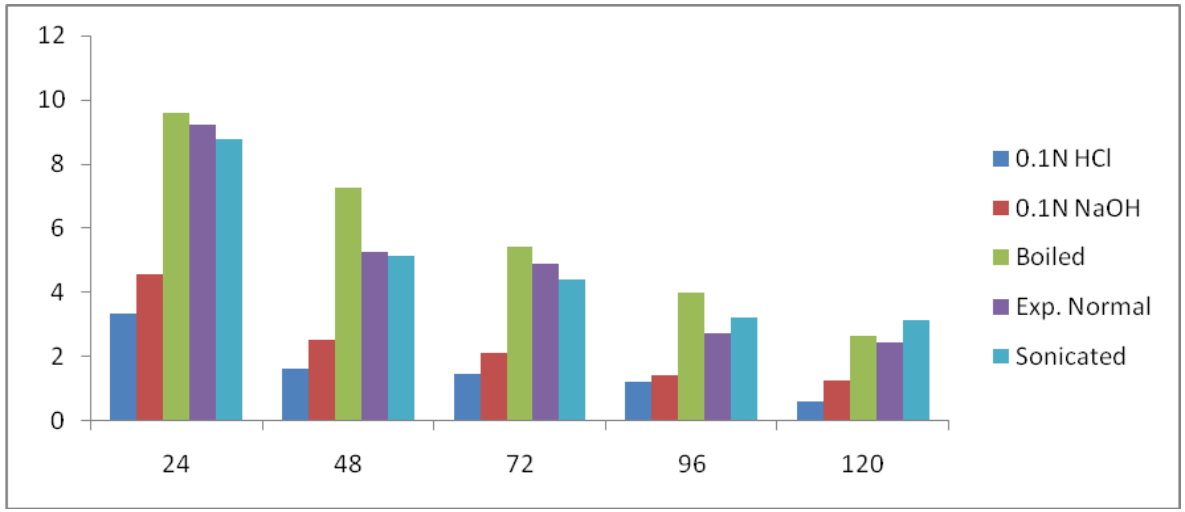


Fig.4 Graphical representation of enzyme activity at various steps of purification process

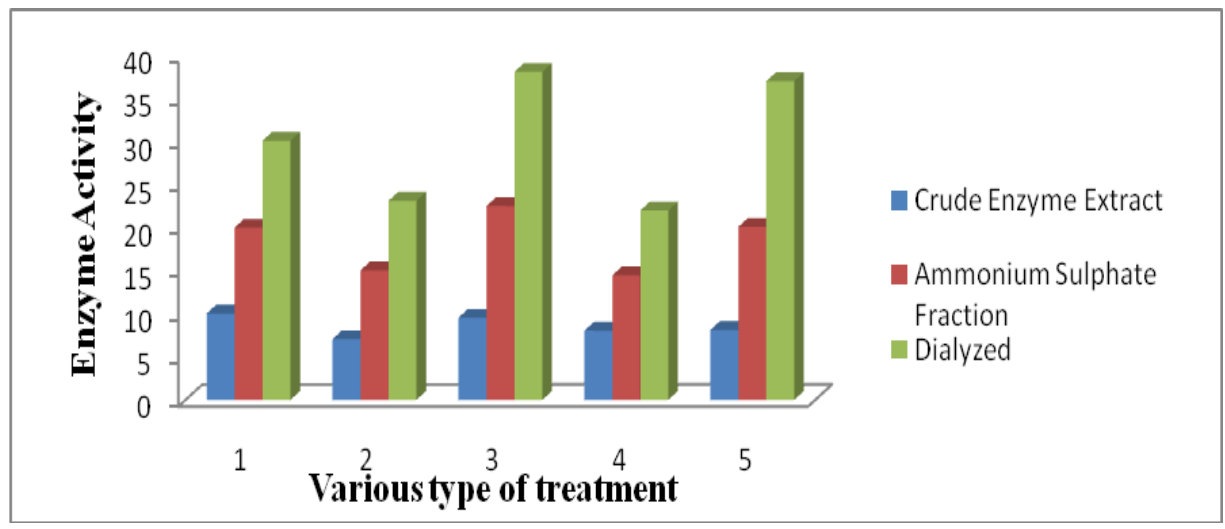

Agricultural byproducts are rich in cellulosic biomass can be exploited as cheap raw material for the producing industrially important enzymes and chemicals (Bigelow and Wyman, 2004). The fermentation medium was inoculated with the fungal strain Trichoderma Viride and was incubated for certain time (96hours) (Fig. 1). The fungal strain was inoculated in different conditions i.e., Acid hydrolysis $(0.1 \mathrm{~N} \mathrm{HCl})$, Alkaline hydrolysis $(0.1 \quad \mathrm{~N} \quad \mathrm{NaOH}), \quad$ Boiled, Experimental Normal and Sonicated (in distilled water, 1h) (Fig. 3). By estimating different treated condition it was found that on $24 \mathrm{~h}$ protein was maximum in sonicated, laccase activity occurred highest in sonicated and reducing sugar was maximum in boiled whereas in $48 \mathrm{~h}$ it was observed that protein was maximum in sonicated, laccase activity occurred highest in normal and reducing sugar was maximum in boiled, again at $72 \mathrm{~h}$ it was recorded that protein was maximum in $0.1 \mathrm{~N} \mathrm{NaOH}$, laccase activity occurred highest in $0.1 \mathrm{~N} \mathrm{NaOH}$ and reducing sugar was maximum in boiled, after which $96 \mathrm{~h}$ showed maximum protein in $0.1 \mathrm{~N} \mathrm{NaOH}$, laccase activity was highest in $0.1 \mathrm{~N} \mathrm{NaOH}$ and reducing sugar was maximum in boiled, and finally, in $120 \mathrm{~h}$ it was analyzed that protein was maximum in sonicated, laccase activity occurred highest in boiled and reducing sugar was maximum in sonicated (Table 1-3). After dialysis laccase showed highest enzyme activity occured 38.18 and 37.098 in boiled and sonicated samples respectively, reported in the below table 4 . Previously Zoya et al., (2014) production of polyphenol oxidase by Bacillus subtilis from submerged fermentation of ash guard peel (Fig. 1-4).

In conclusion, Laccase are promising enzymes to replace the conventional chemical processes of several industries such as the pulp and paper, textile, pharmaceutical, and nanobiotechnology. Thus, efforts have to be made in order to achieve cheap overproduction of laccase in favourable medium. One of the waste products was used in this project i.e. Peel of Ash Gourd, which is found in huge amount near the Petha industries and this not only covering a large area but also becoming a gathering place for harmful diseases-producing microorganisms. Thus, an innovative technique is processed to overcome the above problem and utilizing the peel as the substrate for the production laccase enzyme. Laccase is a biocatalyst that can be used as fodder, it uses solid substrate medium as the source of nutrient. The enzyme activity, growth was checked which were treated in various conditions and purified via various steps i.e. ammonium sulphate and dialysis. After dialysis laccase showed the highest enzyme activity. 


\section{References}

AOAC. 1965. Official methods of analysis of the association of Agricultural chemists, $10^{\text {th }}$ edn., Washingyon, D.C,

Bates, L., Waldren, R.P., Teare, I.D. 1973. Rapid determination of free proline for water-stress studies, Plant and Soil., 39: 205.

Bray, H.G., Thorpe, W.V. 1954. Analysis of phenolic compounds of interest in metabolism, Methods in Biochem. Analysis, 1: 27.

Day, R.A., Underwood, A.L. 1986. Qualitative Analysis, Int. J. Biochem., 5: 194.

Harris, L., Abbasy, M., Yudkin, J. 1935. Vitamin $\mathrm{C}$ reserves of subjects of the voluntary hospital class, Lancet, 5: 1488.

Hedge, J.E., Hofreiter, B.T. 1962. In: Methods in Carbohydrate Chemistry. Phytochem., 17: 420.

Horn, M., Jones, D., Blum, A. 1946. Colorimetric deter-mination of methionine $\mathrm{n}$ proteins and foods, $J$. Biol. Chem., 11: 313.

Jayaraman, J. Laboratory Manual in Biochemistry, J. Biol. Chem., 24:97.

Lowry, O.H., Rosebrough, N.J., Farr, A.L., Randall, R.J. 1951. Protein measurement with the Folin phenol reagent, J. Biol. Chem., 7: 193.

Maynard, Y., Komet, A.J. 1970. Methods in Food Analysis, Academic. J. Nutr., 2: 176.

Nelson, K., Somogyi, M. 1952. Notes on sugar determination, The J. Bio. Chem., 19: 19 .

Reddy, M.B., Love, M. 1999. The impact of food processing on the nutritional quality of vitamins and minerals, $A d v$. Exper. Med. Biol., 45: 234.

Sadasivam, S., Thayumanavan, B. 1984. Plant Foods Hum. Nutr, J. Microbiol., 34: 253.

Updegraff, K., Moris, D.M. 1969. Semimicro determination of cellulose in biological materials, Anal. Biochem., 32: 420.

Zoya, J., Srivastava, S.K. and Tripathi, G.D. 2014. Production and purification of polyphenol oxidase from ash gourd peel. Asian J. Micro, Biotech. \& Envs. Sci., 16: 405.

Zoya, J., Srivastava, S.K., Tripathi, G.D. 2014. Biochemical analysis of ash guard peel optimization for a noble substrate for the growth of Bacillus Subtilis. Indian J. Appl. Res., 4: 63.

\section{How to cite this article:}

Surabhi Mitra, Kanhaiya Tiwari, Shailendra Kumar Srivastava. 2017. Optimization for Production and Partial Purification of Laccase from Ash Gourd Peels. Int.J.Curr.Microbiol.App.Sci. 6(2): 997-1003. doi: http://dx.doi.org/10.20546/ijcmas.2017.602.112 